Article

\title{
Getting to Common Ground: A Comparison of Ontario, Canada's Provincial Policy Statement and the Auckland Council Regional Policy Statement with Respect to Indigenous Peoples
}

\author{
Fraser McLeod ${ }^{1}$, Leela Viswanathan ${ }^{2, *}$, Jared Macbeth ${ }^{3}$ and Graham S. Whitelaw ${ }^{4}$ \\ ${ }^{1}$ School of Urban and Regional Planning, Queen's University, Kingston, ON K7L 3N6, Canada; E-Mail: 8fam@queensu.ca \\ 2 Department of Geography and Planning, Queen's University, Kingston, ON K7L 3N6, Canada; \\ E-Mail: leela.viswanathan@queensu.ca \\ ${ }^{3}$ Walpole Island First Nation Heritage Centre, Walpole Island, ON N8A 4K9, Canada; E-Mail: jared.macbeth@wifn.org \\ ${ }^{4}$ School of Environmental Studies, Queen's University, Kingston, ON K7L 3N6, Canada; \\ E-Mail: graham.whitelaw@queensu.ca \\ * Corresponding author
}

Submitted: 26 December 2017 | Accepted: 22 March 2017 | Published: 3 April 2017

\begin{abstract}
Indigenous rights are crucial to contemporary land use planning and policy in settler states. This article comparatively analyzes the manifest and latent content of the 2014 Provincial Policy Statement (PPS) of Ontario, Canada and the 1999 Auckland Council Regional Policy Statement (ACRPS) of Aotearoa New Zealand in order to evaluate their relative capacity to recognize the rights of Indigenous peoples. While the results show that jurisdiction is an impediment to fostering common ground between Indigenous peoples and settler states, the authors conclude that the PPS and the ACRPS serve vital roles in building dialogue and equitable planning outcomes.
\end{abstract}

\section{Keywords}

Aotearoa; Auckland; Canada; comparative policy; Indigenous; land use planning

\section{Issue}

This article is part of the issue "Urban Forms and Future Cities", edited by Luca D'Acci (Erasmus University Rotterdam, The Netherlands), Tigran Haas (KTH Royal Institute of Technology, Sweden) and Ronita Bardhan (Indian Institute of Technology Bombay, India)

(C) 2017 by the authors; licensee Cogitatio (Lisbon, Portugal). This article is licensed under a Creative Commons Attribution 4.0 International License (CC BY).

\section{Introduction}

Both Aotearoa New Zealand and Canada are settler states and have common asymmetrical structural policy features that have sought to dominate Indigenous peoples $^{1}$ (Hibbard, Lane, \& Rasmussen, 2008; Maaka \& Fleras, 2005). These structures are largely the result of British colonial planning and settlement that was facilitated through the negotiation of foundational documents between the British Crown and Indigenous peo-

\footnotetext{
${ }^{1}$ The collective term 'Indigenous' is used throughout this article when speaking to both settler states in order to allow for an international comparison of key regional land use policy statements from two settler states, and to be consistent with the international context in recognizing First Peoples and communities who have unique legal and political relationships stemming from original occupancy and inherent connections to specific lands prior to settler contact. When referring specifically to the Aotearoa New Zealand context, the term 'Maōri' is used to refer to Indigenous peoples. When referring to the Ontario, Canada context, the term 'First Nations' is used. 'Aboriginal peoples', which refers to First Nations, Métis, and Inuit peoples of Canada collectively as identified in Section 35 of the Constitution Act, 1982 is not used as prevalently because this article emphasises the perspectives of First Nations partners who are involved in this research. The term 'Aboriginal' is only used in certain instances in the article when referring to the Canadian context, the manifest content of the Provincial Policy Statement, and Aboriginal and Treaty rights as recognized and affirmed under Section 35 of the Constitution Act, 1982.
} 
ples grounded in co-existence-Aotearoa New Zealand's 1840 Treaty of Waitangi and Canada's Royal Proclamation of 1763. In Canada, the spirit and intent of the Royal Proclamation of 1763 and the subsequent Treaty of Niagara of 1764, especially regarding Indigenous perspectives and interpretations, has not been lost entirely from the public conscience. ${ }^{2}$ The struggle, however, remains to insist on the continued relevance and significance of these treaties and reports, rather than disregard, in a process of reconciliation (Borrows, 1997; Royal Commission on Aboriginal Peoples [RCAP], 1996; Truth and Reconciliation Commission of Canada [TRC], 2015). In Aotearoa New Zealand, following the formal reinstatement of the Treaty of Waitangi and the establishment of the Treaty of Waitangi Tribunal in 1975, there has been an increased shift towards the formal recognition of its principles and the foundational idea of two nations and their founding partnership (Ericksen, Berke, Crawford, \& Dixon, 2004). While both the Royal Proclamation of 1763 and the Treaty of Waitangi (1840) play significant roles in determining the rights of Indigenous peoples in Canada and Aotearoa respectively, regional policies and plans also deserve close scrutiny regarding the extent to which the settler states formally recognize the rights of Indigenous peoples to lands and resources.

This article proposes that a comparison of the 2014 Provincial Policy Statement (PPS) of Ontario, Canada (Ministry of Municipal Affairs and Housing [MAH], 2014a) and the 1999 Auckland Council Regional Policy Statement (ACRPS) of Aotearoa New Zealand (Auckland Council, 1999), using manifest and latent content analysis of the texts, is warranted in order to evaluate the relative capacity of each policy to recognize the rights of their respective Indigenous peoples, namely, First Nations and Maōri peoples. An international comparison of key regional land use policy statements from two settler states enables a more practical understanding of the strengths and limitations of both policies on the rights of First Peoples. As a research partnership of First Nations in Southern Ontario and academic researchers of non-First Nations cultural backgrounds, the co-authors' work has emerged out of an ongoing interest and need to improve the relationships that exist between First Nation communities and state-based planners as well as to influence state-based planning policies that have historically situated the issues facing Indigenous peoples, especially those who live on reserves in close proximity to cities, as marginal. Following this introduction, a rationale and background to a comparison of the policies is provided, followed by the research methods along with the construction of the theoretical framework used to conduct the manifest and latent content analysis of the policies. The results are then summarized in relation to each policy statement respectively beginning first with findings into the 2014 Provincial Policy Statement and then the
1999 Auckland Council Regional Policy Statement. The subsequent discussion highlights key lessons from the analysis of Ontario's policy and what can be learned from the ACRPS planning context. The article concludes by discussing the implications of this comparative study for planning policy and practice.

\subsection{Rationale}

Our interest in the PPS as a research partnership stems from our ongoing collective efforts to amend the PPS to better support meaningful municipal-First Nations relationships during its 5-year review and our broader collective interests in making inroads and influencing how planning in Southern Ontario unfolds through systematic and strategic policy changes at the provincial-scale (McLeod, Viswanathan, King, Macbeth, \& Whitelaw, 2014). With on-the-ground land use planning and decision-making in Southern Ontario largely directed and guided by The Province through the Planning Act (Government of Ontario, 1990) and PPS, the integration of specific policies concerning Aboriginal peoples in the most recent iteration of the PPS (2014) was recognized as both significant and long overdue (Dorries, 2014; McLeod et al. 2014). Based on the findings of McLeod et al. (2015), the PPS was also recognized as a relatively significant provincial land use and resource management text in its relative capacity at recognizing and supporting First $\mathrm{Na}$ tions, Aboriginal and treaty rights, and embodying past Crown-First Nations relationships, when assessed along with 336 other provincial land use planning and resource management texts. However, to fully comprehend the strengths and limitations of recent changes to the PPS, we identified an immediate need to move beyond relative assessments of Ontario land use planning and resource management texts, and to carry out a comparison with a similar guiding planning policy statement from another settler state.

Aotearoa New Zealand was chosen to support this endeavour at understanding if recent changes to the PPS where truly significant because it is well recognized that this settler state, in comparison to Canada, is far more advanced in its relationships with Maori peoples at the local government scale (Awatere, Harmsworth, Rolleston, \& Pauling, 2013; Participant Three, personal communication, June 13, 2014). Without provinces in Aotearoa New Zealand and following the implementation of the Resource Management Act (RMA) (Ministry for the Environment, 1991), planning authority was primarily devolved to regional and local governments. The ACRPS (1999) was the ideal comparative text with the PPS (2014) as it situates in a similar position within its respective planning hierarchy. As part of a comprehensive study of the effectiveness of Aotearoa New Zealand's new planning regime under the RMA by Ericksen et al.

\footnotetext{
2 Indeed, Call to Action \#45 of the Truth and Reconciliation Commission's Final Report calls for a (new) Royal Proclamation of Reconciliation that builds on both the Royal Proclamation of 1763 and the Treaty of Niagara 1764 as well as "reaffirm[ing] a nation-to-nation relationship between Aboriginal peoples and the Crown." (TRC, 2015, p. 252)
} 
(2004), the ACRPS ranked third overall out of 16 regional policy statements for Māori interests. During the execution of this comparative analysis between March and September 2014, the subsequent iteration of the ACRPS found in a consolidated draft regional policy statement chapter of the Proposed Auckland Unitary Plan (PAUP) had been released for review (Auckland Council, 2013). However, with uncertainty regarding its final contents, approval, and timeframes for when it would be operational, it was determined that the ACRPS would be the ideal policy statement to assess relative to the PPS.

The rationale for executing a comparison between the PPS (2014) and the ACRPS (1999) was also further strengthened by the nature of the geographical regions, the Auckland Region and Southern Ontario, where the two policy statements largely influence everyday planning decisions of local governments. First, as major regions, both the Auckland Region and Southern Ontario comprise of a large proportion of their respective national populations; the Auckland Region comprising 30\% of Aotearoa New Zealand's population and Southern Ontario comprising over $30 \%$ of Canada's population (MAH, 2014b; Memon, Davies, \& Fookes, 2007). Each region is growing fast and provides core economic functions nationally. Each region is also characterized in many places by similar patterns of low-density sprawl (Gordon \& Janzen, 2013; Memon et al., 2007). In terms of governance, both regions during the 1990s faced a series of reforms and amalgamations that resulted in significant reductions of the number of local governments (Memon et al., 2007; Sancton, 2011). Finally, Southern Ontario and the Auckland Region both exist on ancestral lands of Indigenous peoples and planning texts in these regions until recently undervalued Indigenous peoples. Increasingly, Indigenous peoples in each region, parallel to efforts in other regions within settler states, are using land use planning as a form of resurgence, and to their benefit, in order to gain recognition of their rights and inherent connection to the land and their traditional territories (Lane \& Hibbard, 2005; Porter \& Barry, 2013).

\section{Background}

First Nation reserves in Ontario, Canada, many located along borders of urban local governments ${ }^{3}$, have and continue to be controlled under federal jurisdiction and the restrictive confines of the Indian Act (MAH, 2009; RCAP, 1996). Whereas, the provincial government exercises jurisdiction over off-reserve lands, including traditional territories and lands under specific treaties. The integration of provincial land use policies concerning First Nations peoples in Ontario is both significant and long overdue. The Ontario PPS plays a critical role in planning in the Province of Ontario, Canada and also influences the content of other plans within the province. Yet, if there is a conflict between provincial plans and the PPS, provincial plans take precedent unless otherwise stated (MAH, 2014a). The remaining tiers of Ontario's planning hierarchy consist of regional official plans by upper-tier local governments and official plans by lower or singletier local governments, and local implementation tools, such as land use bylaws. In theory, strategic direction from the province tiers down to local authorities, but in certain areas of Southern Ontario, lower-tier local governments must account for the PPS, four provincial plans, and higher-tier plans in their day-to-day planning decisions. There have been four versions of the PPS, including the 1994 Comprehensive Set of Policy Statements, the 1996 PPS, the 2005 PPS and the 2014 PPS. The current PPS came into effect in April 2014 and is significantly different than its predecessors with respect to recognition and support of First Nations (Dorries, 2014). It is posited that in order to fully comprehend the strengths and limitations of the PPS in relation to the rights of First Nations, there is a benefit to moving beyond relative assessment of federal policies across nations and to carrying out an international comparison with a regional plan from another settler state.

Since the early 1990s, Aotearoa New Zealand's planning context has been characterized by an approach, in which regional and territorial authorities under the guidance of the Resource Management Act have had a great degree of discretion in developing policies and plans. Under the RMA, each regional council is required to prepare a regional policy statement, which reflects the regional context and identifies significant resource issues and policies to address their management. Consequently, the Auckland Regional Council Policy Statement came into effect in August 1999 to promote the sustainable management of natural and physical resources in the Auckland Region following a period of major decentralization and reform of planning and governance (Auckland Council, 1999). While the RMA is regarded as the highest strategic tier across all regions in Aotearoa New Zealand, the central government ${ }^{4}$ is also required to provide additional guidance through national policy statements and New Zealand Coastal Policy Statements. Specific to the Auckland Region's planning context, the ACRPS is situated just below the tier of the RMA and has a significant influence on the content of regional plans, regional coastal plans, and district plans, as lower levels of plans and policies cannot be inconsistent with this regional policy statement (Ericksen et al., 2004). Without a parallel governance hierarchy to accompany the policy hierarchy, local and regional governments are required to act in partnership to ensure that the goals of the statute are being met.

\footnotetext{
${ }^{3}$ The term 'local government' is intentionally used throughout this article to allow for a comparison between the PPS (2014) and ACRPS (1999). While 'municipal government' is often cited in the Canadian context as a form of local government and referenced throughout the overall land use planning framework in Ontario; the term 'municipal' is not used in Aotearoa New Zealand and is not transferable. Accordingly, we have intentionally avoided using the term 'municipal' and refer to municipalities and municipal governments in the Ontario context as local governments to support this comparison with the Auckland Region.

${ }^{4}$ The equivalent of the central government in Aotearoa New Zealand is the Federal government in Canada.
} 


\section{Methods and Framework for Analysis}

To assess the 2014 and previous versions of the Ontario PPS and the ACRPS (1999), a literature review, policy document analysis, and four interviews for validation purposes (three with First Nations community representatives and one planning expert in Southern Ontario) were conducted in this research from March to September 2014 to ensure triangulation, internal validity of initial findings and external validity of the analytic framework. The interviews are therefore integrated into several sections of the paper rather than as standalone findings. This research examines both manifest and latent content of policy statements and their associated higher-tier legislation with respect to Indigenous peoples and not their effects or implementation. In turn, the primary method for further inquiry was document analysis (Cope, 2010). The justifications for the use of document analysis draws heavily from Barry and Porter (2011) and Porter and Barry (2013) as the critical examination of planning law and governance in British Columbia, Canada and Victoria, Australia, evident in both articles, highlights the need to analyze statutory planning texts, including legislation, policies, guidelines and regulations to better understand planning's conflicting relationship with Indigenous peoples. It became clear that for this research it was just as important to understand the content of strategic-level policy statements that shape the everyday as it was to understand daily practices and processes that can advance Indigenous peoples' rights, concerns, and knowledge as well as create uneven power relations and starting points for communities.

Yet, analytical frameworks that assist in evaluating and making inferences about provincial and regional policy with respect to Indigenous peoples are relatively limited; this required our research partnership to construct an analytical framework by drawing out specific elements from the literature. To elaborate, the few frameworks that do exist relating to the New Zealand planning context, primarily Berke, Ericksen, Crawford and Dixon (2002) and Ericksen et al. (2004), tend to "simplify Indigenous recognition to a matter of accommodating greater numbers of Indigenous peoples in mainstream decisionmaking forums" (Barry \& Porter, 2011, p. 172). While these authors focused on New Zealand's environmental planning regime under RMA, including analyzing a number of plans and policy statements in great detail along with their successes and failures, the actual questions and criteria that guided their analysis were too RMAfocused, making it difficult to transfer to a comparative study. As a result, with limited studies regarding the content analysis of Crown and local government planning policies in relation to Indigenous peoples and no clear comparative framework for planning policy statements to replicate, the research partnership had to engage in theory development (Yin, 2009). Informed by the ideas of our research partnership and relevant academic literature $^{5}$, a four-tiered framework to assess the manifest and latent content of each policy statement document was developed as a part of an iterative process to address this void in the literature. It was further validated through expert interviews.

\section{Four-Tiered Framework}

The framework implemented in the document analysis of the manifest and latent content of the policy statements consists of four elements: clarity, recognition, willingness and active reconciliation. Each element is guided by questions and indicators that informed the policy analysis of relevant sections of each of the planning texts under scrutiny. Authors that broadly informed the foundations of corresponding elements of the framework are also identified with the corresponding elements of the framework. Grounding the analytical framework in existing literature was done to ensure the implications of this research would link to larger discussions of planning theory and practice. This analytical framework is by no means complete and should be treated as a living document to learn from and build upon.

\subsection{Clarity}

Starting with clarity, as noted in Table 1 , the first element of framework is intended to chart the position of individual policy statements within their respective planning frameworks and evaluate whether they vertically connect to higher-tier legislation and lower-tier plans, such as official plans in Southern Ontario and district plans in the Auckland Region. Drawing from Ericksen et al. (2004) and Berke et al. (2002), who used multiple methods to evaluate how well regional and district plans as well as certain regional policy statements in Aotearoa New Zealand accounted for the mandate of the RMA and key provisions relating to Māori interests and the Treaty, the first question and set of primary indicators (Table 1) were established to analyze what guidance is provided by higher-tier legislation for each policy statement. The second question and set of indicators (Table 1) draws from the concepts of strategic planning and tiering (Healey, 2006; Noble, 2009) and are intended to identify if lowertier planning authorities have to conform to policy statements through reviewing the terminology in key provisions of the Planning Act (1990) and the RMA (1991).

\subsection{Recognition}

Recognition, the second element of the framework, is meant to focus the policy analysis on how state-based planning, as mediated through texts, extends horizon-

\footnotetext{
${ }^{5}$ It is important to note that ideas and concepts of authors listed within individual elements of the framework collectively influenced the development of that element of the framework. For instance, Noble (2009) influenced the research partnership in focusing on tiering and understanding how overarching legislation at the strategic level tiers down to individual policy statements.
} 
Table 1. Key aspects to Clarity in reference to the Ontario Provincial Policy Statement and the Auckland Council Regional Policy Statement.

\begin{tabular}{|c|c|c|}
\hline \multirow[b]{2}{*}{ Question } & \multicolumn{2}{|c|}{ Primary Indicators } \\
\hline & PPS (Ontario, Canada) & $\begin{array}{l}\text { ACRPS (Auckland Region, } \\
\text { Aotearoa New Zealand) }\end{array}$ \\
\hline \multirow{4}{*}{$\begin{array}{l}\text { Do higher-tier } \\
\text { legislation provide a } \\
\text { clear mandate on } \\
\text { Indigenous issues and } \\
\text { rights for the policy } \\
\text { statement? }\end{array}$} & $\begin{array}{l}\text { Within the manifest content of the Planning } \\
\text { Act (1990) is there reference to: }\end{array}$ & $\begin{array}{l}\text { Within the manifest content of the RMA is } \\
\text { there reference to: }\end{array}$ \\
\hline & $\begin{array}{l}\text { 1. Indigenous peoples (First Nations; } \\
\text { Aboriginal peoples; Indian Band; First } \\
\text { Nation Council) }\end{array}$ & $\begin{array}{l}\text { 1. Indigenous peoples (Māori; Indigenous } \\
\text { Peoples; Tangata Whenua; Mana Whenua) }\end{array}$ \\
\hline & $\begin{array}{l}\text { 2. Aboriginal \& treaty rights (section } 35 \text { of } \\
\text { the Constitution Act, 1982; specific } \\
\text { treaties) }\end{array}$ & \\
\hline & 3. The Royal Proclamation of 1763 & \\
\hline
\end{tabular}

Do lower-tier planning

authorities have to

conform to the policy

statement when making

Assessment of terminology in section 3 of

the Planning Act (1990)

Assessment of terminology in section 59-62

of the RMA

informed land use

planning decisions?

tally outwards to the edges of planning to draw in Indigenous peoples' rights, concerns, claims and knowledge that have historically been overlooked. The first question and set of indicators (Table 2) centre on identifying the highly circumscribed sites of recognition within each policy statement where Indigenous peoples, treaties, rights and traditional territories are brought forward (Barry \& Porter, 2011; Porter \& Barry, 2013). The second question and set of indicators (Table 2 ) then examine the latent content of flagged sites of recognition to evaluate whether Indigenous peoples are framed by the discourse of policy statements as just another stakeholder (Healey, 1997) or as equal and active partners with equal footing in the planning process (RCAP, 1996; Borrows, 1997; Maaka \& Fleras, 2005; Porter, 2006). Understanding what forms that recognition takes in policy statements gives further insight into how lower-tier planning authorities recognize and engage with Indigenous peoples and more generally, the continued existence of asymmetrical relations between dominant planning frameworks and Indigenous peoples (Hibbard et al., 2008).

\subsection{Willingness}

Willingness is the third element of the framework, as noted in Table 3. Questions that inform this element and set of indicators (Table 3 ) are grounded in the work of McLeod et al. (2015), and are intended to identify the degree of willingness of the Crown set out in each policy statement to honour past relations. Still, historically, Indigenous peoples do not enter planning systems on equal terms, and consultation and accommodation policies may not fundamentally change a community's uneven starting point in the planning process (Hibbard et al., 2008). Thus, in certain instances different degrees of willingness within texts may not change the status quo significantly and improve Indigenous peoples' ability to shape local decision-making (Dorries, 2014; Participant Four, personal communication, July 23, 2014).

\subsection{Active Reconciliation}

Active reconciliation, the final element of the framework is best understood theoretically as multifaceted and embodies a set of temporal connections to the past and future, which together have the potential to enable planning as a system of representation to become unsettled and transformed by acknowledging what has happened in the past, figuring out what is going to be done about it and then following through with action. According to the Truth and Reconciliation Commission of Canada (2015, p. 6), reconciliation means "establishing and maintaining a mutually respectful relationship between Aboriginal and non-Aboriginal peoples in [Canada]. In order for that to happen, there has to be awareness of the past, acknowledgement of the harm that has been inflicted, atonement for the causes, and actions to change behaviour." In Aotearoa, similarly, active reconciliation with respect to the framework is not a passive act that is a means to an end as has been the case in Canada through formal apologies (Fairweather, 2006). Reconciliation has no end state as it is an active and genuine process to change and transform uneven planning relations through first acknowledging planning's past and current role in injustices towards Indigenous peoples. Furthermore, reconciliation acknowledges the limits of planning frameworks that continue to be defined by dominant society, that Indigenous peoples have an inherent right to 
Table 2. Key aspects to Recognition in reference to the Ontario Provincial Policy Statement and the Auckland Council Regional Policy Statement.

\begin{tabular}{|c|c|c|}
\hline \multirow[b]{2}{*}{ Question } & \multicolumn{2}{|c|}{ Primary Indicators } \\
\hline & PPS (Ontario, Canada) & $\begin{array}{l}\text { ACRPS (Auckland Region, } \\
\text { Aotearoa New Zealand) }\end{array}$ \\
\hline \multirow{5}{*}{$\begin{array}{l}\text { What form does } \\
\text { recognition of } \\
\text { Indigenous peoples, } \\
\text { treaties, rights and } \\
\text { traditional territories } \\
\text { take within the policy } \\
\text { statement? }\end{array}$} & $\begin{array}{l}\text { Within the manifest content of policy } \\
\text { statement is there reference to: }\end{array}$ & $\begin{array}{l}\text { Within the manifest content of policy } \\
\text { statement is there reference to: }\end{array}$ \\
\hline & $\begin{array}{l}\text { 1. Indigenous peoples (First Nations; } \\
\text { Aboriginal Peoples; Indian Band; First } \\
\text { Nation Council); }\end{array}$ & $\begin{array}{l}\text { 1. Indigenous peoples (Māori; Indigenous } \\
\text { peoples; Tangata Whenua; Mana Whenua) }\end{array}$ \\
\hline & $\begin{array}{l}\text { 2. Aboriginal \& treaty rights (section } 35 \text { of } \\
\text { the Constitution Act, 1982; specific } \\
\text { treaties; Royal Proclamation of } 1763 \text { ) }\end{array}$ & $\begin{array}{l}\text { 3. Traditional territories (ancestral lands; } \\
\text { ancestral taonga) }\end{array}$ \\
\hline & $\begin{array}{l}\text { 3. Traditional territories (traditional } \\
\text { territories; sites of cultural significance to } \\
\text { individual nations) }\end{array}$ & $\begin{array}{l}\text { 4. Indigenous language, expressions, and } \\
\text { worldviews }\end{array}$ \\
\hline & $\begin{array}{l}\text { 4. Indigenous language, expressions, and } \\
\text { worldviews }\end{array}$ & \\
\hline \multirow{3}{*}{$\begin{array}{l}\text { How are Indigenous } \\
\text { peoples framed within } \\
\text { planning processes } \\
\text { based on the textual } \\
\text { evidence of the policy } \\
\text { statement? }\end{array}$} & $\begin{array}{l}\text { Within the latent content of the policy } \\
\text { statement is there reference to: }\end{array}$ & $\begin{array}{l}\text { Within the latent content of the policy } \\
\text { statement is there reference to: }\end{array}$ \\
\hline & $\begin{array}{l}\text { 1. Indigenous peoples as stakeholders in } \\
\text { planning processes; or }\end{array}$ & $\begin{array}{l}\text { 1. Indigenous peoples as stakeholders in } \\
\text { planning processes; or }\end{array}$ \\
\hline & $\begin{array}{l}\text { 2. Indigenous peoples as equal and active } \\
\text { partners with equal footing in planning } \\
\text { processes. }\end{array}$ & $\begin{array}{l}\text { 2. Indigenous peoples as equal and active } \\
\text { partners with equal footing in planning } \\
\text { processes. }\end{array}$ \\
\hline
\end{tabular}

Table 3. Key aspects to Willingness in reference to the Ontario Provincial Policy Statement and the Auckland Council Regional Policy Statement.

\begin{tabular}{|c|c|c|}
\hline \multirow[b]{2}{*}{ Question } & \multicolumn{2}{|c|}{ Primary Indicators } \\
\hline & PPS (Ontario, Canada) & $\begin{array}{l}\text { ACRPS (Auckland Region, } \\
\text { Aotearoa New Zealand) }\end{array}$ \\
\hline \multirow{4}{*}{$\begin{array}{l}\text { What is the degree of } \\
\text { willingness of the Crown } \\
\text { set out in each } \\
\text { individual policy } \\
\text { statement to honour } \\
\text { past relations and } \\
\text { acknowledge and } \\
\text { engage with Indigenous } \\
\text { peoples, perspectives } \\
\text { and concerns? }\end{array}$} & $\begin{array}{l}\text { Within the manifest and latent content of } \\
\text { the policy statement is there reference to: }\end{array}$ & $\begin{array}{l}\text { Within the manifest and latent content of } \\
\text { the policy statement is there reference to: }\end{array}$ \\
\hline & $\begin{array}{l}\text { 1. Reference to consultation with respect to } \\
\text { Indigenous peoples }\end{array}$ & $\begin{array}{l}\text { 1. Reference to consultation with respect to } \\
\text { Indigenous peoples }\end{array}$ \\
\hline & $\begin{array}{l}\text { 2. Reference to accommodation with respect } \\
\text { to Indigenous peoples }\end{array}$ & $\begin{array}{l}\text { 2. Reference to accommodation with respect } \\
\text { to Indigenous peoples }\end{array}$ \\
\hline & $\begin{array}{l}\text { 3. Reference to consent with respect to } \\
\text { Indigenous peoples }\end{array}$ & $\begin{array}{l}\text { 3. Reference to consent with respect to } \\
\text { Indigenous peoples }\end{array}$ \\
\hline
\end{tabular}

self-determination and that there is an imminent need for effective and sustained equitable relationship building to restore shared territories. While reconciliation is the responsibility of all of society to address denial and make fundamental changes and restitution (Corntassel \& Holder, 2008), state-based planning also has a significant role to play in its advancement.

The overarching question and four primary indicators (Table 4) that inform this element of the analyti- cal framework were chosen because they act as points of reference into how prepared governing officials and planning policymakers are in actively challenging and restructuring the status quo of Indigenous peoples-state relations based on the content of planning texts. The four indicators provide insight into what may be missing from current planning policy and collectively draw on Barry and Porter (2011), Borrows (1997), Corntassel and Holder (2008), Hibbard et al. (2008), Maaka and 
Table 4. Key aspects to Active Reconciliation in Reference to the Ontario Provincial Policy Statement and the Auckland Council Regional Policy Statement.

\begin{tabular}{|c|c|c|}
\hline \multirow[b]{2}{*}{ Question } & \multicolumn{2}{|c|}{ Primary Indicators } \\
\hline & PPS (Ontario, Canada) & $\begin{array}{l}\text { ACRPS (Auckland Region, } \\
\text { Aotearoa New Zealand) }\end{array}$ \\
\hline \multirow{5}{*}{$\begin{array}{l}\text { How does the policy } \\
\text { statement reconcile } \\
\text { both the limitations of } \\
\text { state-based planning } \\
\text { efforts with respect to } \\
\text { Indigenous peoples and } \\
\text { the opportunities to } \\
\text { support and sustain } \\
\text { relationships and } \\
\text { mutual understanding } \\
\text { amongst Indigenous and } \\
\text { non-Indigenous } \\
\text { peoples? }\end{array}$} & $\begin{array}{l}\text { Within the manifest and latent content of } \\
\text { the policy statement is there reference to: }\end{array}$ & $\begin{array}{l}\text { Within the manifest and latent content of } \\
\text { the policy statement is there reference to: }\end{array}$ \\
\hline & $\begin{array}{l}\text { 1. Acknowledgement of planning's } \\
\text { involvement in historical and ongoing } \\
\text { injustices towards Indigenous peoples, } \\
\text { rights and traditional territories }\end{array}$ & $\begin{array}{l}\text { 1. Acknowledgement of planning's } \\
\text { involvement in historical and ongoing } \\
\text { injustices towards Indigenous peoples, } \\
\text { rights and traditional territories }\end{array}$ \\
\hline & $\begin{array}{l}\text { 2. Acknowledgement of the current } \\
\text { limitations of planning in understanding } \\
\text { Indigenous peoples' rights, concerns, } \\
\text { claims and knowledge and the need for } \\
\text { Indigenous voices and partnerships to } \\
\text { actively transform planning }\end{array}$ & $\begin{array}{l}\text { 2. Acknowledgement of the current } \\
\text { limitations of planning in understanding } \\
\text { Indigenous peoples' rights, concerns, } \\
\text { claims and knowledge and the need for } \\
\text { Indigenous voices and partnerships to } \\
\text { actively transform planning }\end{array}$ \\
\hline & $\begin{array}{l}\text { 3. Acknowledgement of Indigenous peoples' } \\
\text { inherent right to self-determination }\end{array}$ & $\begin{array}{l}\text { 3. Acknowledgement of Indigenous peoples' } \\
\text { inherent right to self-determination }\end{array}$ \\
\hline & $\begin{array}{l}\text { 4. Acknowledgement of the need for } \\
\text { building effective and sustained equitable } \\
\text { relationships between the Crown, } \\
\text { Indigenous peoples and non-Indigenous } \\
\text { communities on common ground and } \\
\text { actively following through }\end{array}$ & $\begin{array}{l}\text { 4. Acknowledgement of the need for } \\
\text { building effective and sustained equitable } \\
\text { relationships between the Crown, } \\
\text { Indigenous peoples and non-Indigenous } \\
\text { communities on common ground and } \\
\text { actively following through }\end{array}$ \\
\hline
\end{tabular}

Fleras (2005), Porter (2006), Porter (2010), the RCAP (1996), Regan (2010), Sandercock (2004), Turner (2006) and the UN Declaration on the Rights of Indigenous Peoples (United Nations, 2007). Active reconciliation along with the previous three elements, serve to advance discussions about how we can move from the conceptual to actual changes in order to plan differently through mutual understanding and learning between Indigenous and non-Indigenous peoples on common ground.

\section{Results}

Results are presented in two major parts - the current Ontario PPS (2014) and the ACRPS (1999). Keeping with the context of Indigenous peoples-state relations in Southern Ontario and the Auckland Region, findings from the analytical framework relating to the PPS refer to First Nations, while findings relating to the ACRPS refer to Māori people, iwi, Mana Whenua or Tangata Whenua. Certain terms will be used interchangeably. Prior to the current PPS (2014), the three earlier versions of the Ontario PPS (the 1994 Comprehensive Set of Policy Statements, the 1996 PPS and the 2005 PPS) differed significantly in terms of content and policies, and came into effect under three different provincial governments. Yet, they share one major commonality: there was no clear acknowledgment of First Nations or Aboriginal peoples in general in any of the three planning texts. These earlier iterations and their inability to recognize and support First Nations is significant to document because it provides a baseline of where the PPS has come from, heightening the importance of recent changes to this policy statement.

\subsection{The Ontario Provincial Policy Statement}

\subsubsection{Clarity}

The Planning Act (1990) in its most recent amended form does not provide a clear mandate on First Nations issues and rights as distinct communities continue to be framed as 'public bodies'. There is also no mention of section 35 of the Constitution Act, 1982, which protects Aboriginal and treaty rights or a clear connection to the principles of Royal Proclamation of 1763 in this guiding legislation. In terms of conformity, according to subsection 3(5) of the Planning Act (1990), planning authorities, including local governments, a local board, a planning board and provincial ministers 'shall be consistent with' the current PPS when exercising their authority over a planning matter. This subsection requires that all official plans at the local government-scale be in line with the current PPS. However, the PPS is read in conjunction with provincial plans, and if there is a conflict, provincial plans take precedent unless otherwise stated (MAH, 2014a). For example, cer- 
tain legislation, such as the Green Energy Act (Government of Ontario, 2009), can also override the current PPS as well as provincial and official plans. Thus, conformity to the PPS through official plans in certain regions of Southern Ontario may not be as straightforward due to overarching and conflicting provincial plans and legislation. This reality highlights the importance of developing new provisions based on First Nations-led amendments in other policies relating to the Southern Ontario context that may overwrite the PPS.

\subsubsection{Recognition}

In contrast to the void of recognition of the three previous PPS, the current PPS (2014) addresses this element to a certain extent. First, there is direct recognition of First Nations through use of the broad term Aboriginal, which under the Constitution Act, 1982 refers to First Nations, Métis and Inuit collectively. The use of the term Aboriginal in conjunction with peoples and communities occurs in six instances, primarily around discussions and definitions around conserving cultural heritage and archaeological resources. There is also recognition of existing Aboriginal and treaty rights in section 4.0 of the PPS regarding implementation and interpretation as it outlines that the policy statement "shall be implemented in a manner that is consistent with the recognition and affirmation of existing Aboriginal and treaty rights in section 35 of the Constitution Act, 1982" (MAH, 2014a, p. 33). By recognizing existing rights protected under section 35 , the policy statement avoids previous uncertainties attached with placing the onus on practitioners to read the PPS in conjunction with overarching federal and provincial policies. This acknowledgement of section 35 in the PPS visibly brings Aboriginal and treaty rights to the forefront of Ontario's planning framework.

The content analysis also highlighted several gaps in recognition. For instance, specific treaties and individual agreements to Ontario between the Crown and First Nations as well as the principles of the Royal Proclamation of 1763 are not recognized. Most noticeably, there is no recognition of the land and traditional territories in the most recent policy statement. It would behoove the Province to recognize traditional territories and bring them to the forefront of planning policies in Ontario because these lands are often at the centre of ongoing First Nations grievances and disputes over continued development on contested territories (Ipperwash Inquiry, 2007; DeVries, 2012; Participant Four, personal communication, July 23, 2014). Dorries (2012) has noted how planners in Canada remain ignorant, if not uninformed, to recognize Aboriginal treaty rights on lands held by the Crown, including reserves, treaty lands, and traditional territories upon which cities are located. Furthermore, without recognition in the policy statement, it cannot be assumed that all non-Indigenous practitioners and local government councils would factor traditional territories into daily decision-making. In particular, there remains a prevalent assumption amongst non-First Nations communities that provincial lands have been honourably settled and that First Nations do not have a continued interest or right to the land, especially in already developed areas (Participant Two, personal communication, June 12, 2014). These types of assumptions, often reproduced in planning policy, counter meaningful opportunities to educate practitioners and the public at large into the significance of differing and equally valid Indigenous perspectives. Lastly, based on the content of the PPS, First Nations continue to be framed as stakeholders in planning processes; this is an enormous problem. By framing First Nations as stakeholders rather than as owners and keepers of the land, the Crown and the government perpetuate the denial of First Nations to their inherent and treaty rights (Turner, 2006). As noted by Porter (2006, p. 389) the term 'stakeholder' when applied to Indigenous people, "fails to appreciate their unique status as original owners of country that was wrested from them by the modern, colonial state" and when reinforced within a framework of inclusion, could simply reinforce paternalistic relationships between the Crown and Indigenous peoples rather than an emancipatory relationship that could support if not uphold Indigenous sovereignty.

\subsubsection{Willingness}

The importance of consulting First Nations "on planning matters that may affect their rights and interests" as outlined in Part IV's vision statement signals a degree of willingness that was absent from previous policy statements (MAH, 2014a, p. 4). There are also new sections that emphasize consultation through stating that planning authorities 'shall consider' Aboriginal interests in conserving cultural heritage and archaeological resources (section 2.6.5) and 'are encouraged' to coordinate planning matters with Aboriginal communities (section 1.2.2). Despite the use of less firm language in the latter, the integration of these new section represents a step forward for land use planning policy in Ontario. While the word 'accommodate' is not cited in the latest PPS, the direct integration of section 35 of the Constitution Act, 1982 in section 4.3 could be interpreted as a form of accommodation with respect to First Nations. In order to ensure that the implementation of the PPS' policies do not infringe on existing Aboriginal and treaty rights, consultation and in certain instances accommodation would be required. Reference to consent with respect to First Nations remains non-existent in the entire PPS. Nevertheless, consent may already be part of the on-the-ground processes and relations between certain local governments and neighbouring First Nations even if it is absent in the province's minimum standards of the PPS. The duty to consult and accommodate First Nations should be expected of the Province and thereby also anticipated within the PPS. The duty to consult is legally upheld by the Crown, as represented by the Government of Canada and the provinces, as well as by local governments (or 
municipalities) by virtue of being a third party to the Crown (Fraser \& Viswanathan, 2013).

\subsubsection{Active Reconciliation}

The four indicators for active reconciliation were either absent or minimally visible in the review of the latent content of the latest PPS. There was no connection made between land use planning policies and historical and ongoing injustices towards First Nations, Aboriginal and treaty rights and traditional territories. A simple reference to the findings of the Ipperwash Inquiry (2007) or the Royal Commission on Aboriginal Peoples (1996) would address this inherent gap in understanding. In terms of an acknowledgement of the limitations of planning, Section 1.2.2 under very liberal interpretations could be construed as recognition of this limit and the need to coordinate with First Nations, but it still gives authority and agency to planning authorities to decide if it should coordinate. There was also no recognition in the PPS of First Nations' inherent right to self-determination. Lastly, the policies relating to First Nations collectively, particularly those focused enhancing dialogue and communication between First Nations and local governments, could be viewed as a necessary step towards more tangible policies regarding building effective and sustained equitable relationships.

\subsection{The 1999 Auckland Council Regional Policy Statement}

\subsubsection{Clarity}

The RMA did provide a clear mandate on Māori issues and rights for Auckland Council in preparation of a regional policy statement. First, subsection 6(e), outlines that "the relationship of Māori and their culture and traditions with their ancestral lands, water, sites, waahi tapu and taonga" is a matter of national significance and shall be recognized and provided for by all persons exercising functions and authority under the Act (1991, p. 69). Second, in subsection 7(a), there is recognition of kaitiakitanga and accordingly, plans and policies must 'have regard to' the exercise of guardianship by local Māori people. Third, section 8 identifies that principles of the Treaty 'shall be taken into account'.

In addition to these broad provisions that apply to all decisions and plans under the RMA, there are also policies specific to regional policy statements. Subsection $61(2 \mathrm{~A})(\mathrm{a})$ outlines that when a regional council is preparing or altering a regional policy statement they 'must take into account' any relevant iwi planning document if it is brought forward by a recognized iwi authority. Subsection 62(1) (b) then identifies that any regional policy statement 'must state' resource management issues of regional iwi authorities. In terms of conformity, according to subsection 67(3) (c) and 75(3) (c), lower-tier regional plans and district plans 'must give effect' to their respective regional policy statement.

\subsubsection{Recognition}

There is significant and meaningful recognition of Māori people, the Treaty, rights and ancestral lands in the ACRPS. To begin, the first page of the policy statement starts with Māori proverb in both Māori and English. In section 2.2 regarding the current context of the Auckland Region, there is acknowledgement that the Māori were first occupants of the region and New Zealand. Subsections 2.4.8 and 2.4.9, outlines that in accordance with the RMA that the relationship of Māori with their ancestral lands and resources are matters of national significance and that Tangata Whenua are under significant pressure to protect and manage their ancestral sites and lands. There is also an admission that the Treaty of Waitangi has been undervalued historically in the management of resources in the region within subsection 2.4.9.

The highest frequency of recognition occurs in Chapter 3 as it is entirely dedicated to regional resource issues significant to local Māori people. It lists Māori groups that were consulted for the ACRPS and summarizes key issues, objectives, policies, methods and justifications. Regarding the recognition of the Treaty of Waitangi, Appendix E of the Treaty provides the three accepted versions of the Treaty (English text, Māori text, translation of Māori text) while the principles of the Treaty are referenced in several instances throughout the text. The actual principles are never defined in greater detail beyond these references. With respect to traditional territories, there are clear instances of recognition of ancestral lands and taonga, but they are typically referenced with section 6(e) of the RMA and directly paraphrased from the RMA (1991), which does not account for the context of the Auckland Region. Through referencing both English and Māori terms for Māori people, recognizing (with limitation) the customary authority of Tangata Whenua over resource management, and emphasizing the need to take into account iwi planning documents, the policies found in this planning text move away, to a certain degree, from the traditional stakeholder model to embody a partnership approach. However, there are external limitations to these forms of text-based recognition as planning is still largely dominated by non-Indigenous perspectives and local non-Indigenous councillors who oversee planning may not be "ready to genuinely share power with iwi" (Ericksen et al., 2004, p. 131).

\subsubsection{Willingness}

The ACRPS emphasizes a relatively strong willingness to honour past relations through integrating consultation and accommodation with respect to Māori people in different policies, methods, reasons and anticipated results. The most apparent examples of a willingness to consult occur in specific policies and methods in Chapter 3. For instance, policy 3.4.7 identifies that the involvement of Tangata Whenua in the development, implementation or review of the ACRPS as well as regional and district 
plans "shall be undertaken in ways which...(iv) provide for early and effective consultation" (Auckland Council, 1999, Chapter 3, p. 3). To give effect to this policy, several methods are provided, including the requirement that the Auckland Council through consultation with local Tangata Whenua develop up-to-date consultation guidelines and checklists and ensure a directory of Māori organizations and representatives are available to assist government and third parties with consultations. The Auckland Council and territorial authorities are also required to encourage applicants to consult affected Māori groups prior to submitting resource consents. To ensure the recognition and protection of sacred places, sites and resources, where agreed upon by Tangata Whenua (policy 3.4.2), planning authorities are required to consult in order to identify sites in plans and provide appropriate levels of protection.

Under the framework of the ACRPS, regional and district plans 'will make' provisions to protect "sites and areas of special significance to Tangata Whenua" where such sites are recognized to exist based on Indigenous knowledge, but not identified in conventional planning maps or diagrams (Auckland Council, 1999, Chapter 3, p. 3). This form of accommodation gives agency to Māori people to shape the dominant state-based planning framework without having to conform to it to ensure their claims and knowledge are valid. Policy 3.4.10 further highlights a degree of accommodation by stating that the management of resources 'shall take into account' relevant Treaty claims and customary rights of Māori people. Lastly, in keeping with Policy 3.4.13 to promote the 'practical expression' of kaitiakitanga, the ethic of guardianship, the Auckland Council and territorial authorities must identify opportunities to include iwi authorities in the management of ancestral sites and resources, including the potential to transfer authority and functions. These features of the policy statement together express a willingness to recognize and engage with Indigenous peoples, perspective and concerns. However, in approximately 168 instances of the use of word 'consent' there was no documentation of the term in relation to Māori people. This lack of textual evidence of consent with respect to Māori demonstrates a clear limitation of the policy statement and planning in general in the Auckland Region. It focuses on increasing Indigenous participation without a significant willingness to give Māori people greater authority or autonomy, which limits any opportunity to address the larger uneven structures of planning frameworks.

\subsubsection{Active Reconciliation}

In contrast to the current PPS (2014) and its predecessors, the ACRPS does engage with certain aspects of active reconciliation. To begin, section 3.2.3 of the ACRPS acknowledges to a certain extent planning's involvement in historical and ongoing injustices towards Māori people and highlights the following factors (Auckland Council, 1999, Chapter 3, p. 3) regarding the impact of the Crown's breach of the Treaty in Auckland, including: "the alienation of land and other resources which were guaranteed to Tangata Whenua; loss of the use and enjoyment of resources as a result of pollutive discharges to ancestral waters; [and] the over-riding of the customary rights and responsibilities over ancestral taonga". Section 3.2.3 of the ACRPS also recognizes how the Crown has "individualised title and granted use rights in respect of taonga (eg., minerals, water, and land) to individuals and organisations" such that, "[t]he Crown receives income as a result of those actions" (Auckland Council, 1999, Chapter 3, p. 3).

There is also acknowledgement of the limitation of planning and the need for Indigenous involvement in planning processes and decision-making the ACRPS. Section 3.2.2 lists five general factors identified by Māori communities that have inhibited the realization of statutory provisions and their full participation in planning processes, including among others a general misunderstanding of Māori values and limited techniques to ensure early and effective engagement in planning processes (Auckland Council, 1999, Chapter 3, p. 3). Overall, the policy statement fared relatively well with respect to these two indicators. However, the ACRPS' approach to active reconciliation becomes progressively vague and limited when the two final indicators are critically taken into consideration. First, recognition of selfdetermination is not clear or explicit within the latent content of the policy statement. Although there is reference of rangatiratanga, which has become synonymous with the Indigenous right to self-determination, it is defined with the policy statement as "full tribal authority", which can be understood as local Indigenous organizations that have been given certain authorities over the management of resources and delivery of services by the state following New Zealand's major period of decentralization (Auckland Council, 1999, Appendix D, p. 12). This narrow interpretation juxtaposes others that exist (see Maaka \& Fleras, 2005). The fourth indicator, an acknowledgement of the need for building effective and sustained equitable relationships, is partially recognized in the latent content of the policy statement through an apparent emphasis on strengthen ties with Māori people and authority in different sections. In particular, policies regarding the potential transfer of authority to Māori organization or iwi authorities could be interpreted as recognition of this need, but this transfer still occurs on planning's own terms and in the face of pressures from dominant non-Indigenous interests. These last two aspects of active reconciliation further illustrate the limits of this policy statement in its own ability to support a fundamental shift towards finding common ground.

\section{Discussion}

Based on the analysis, the Government of Ontario has made significant advances with respect to recognition and support of First Nations in the most recent PPS. The content of 2014 PPS signals a long-awaited change in ap- 
proach towards recognition and support of First Nations' rights and interests in provincial land use planning policy. One of the most significant changes to the PPS has been the integration of First Nations within policies and definitions of conserving cultural heritage and archaeological resources. In particular, the use of 'shall' and stronger language in section 2.6.5 demonstrates that the Province is willing to engage with a critical issue in Southern Ontario for First Nations and ensure that community concerns are part of the planning process. Recognition of section 35 of the Constitution Act, 1982 was also significant because it not only recognizes and reaffirms existing Aboriginal and treaty rights, but it brings them to forefront of local government planning and decision-making, and into the conscience of practitioners (Participant One, personal communication, June 12, 2014).

Developments since the 2014 PPS offer some hope to the way in which government leaders are seeking ways to enhance Ontario's relations with First Nations. In August 2015, the Chiefs of Ontario signed a Political Accord between First Nations and the Government of Ontario (2015) (see http://www.chiefs-ofontario.org/node/1168, paragraph 5) in order to:

- Promote...bi-lateral relationships between First Nations and Ontario by strengthening and supporting existing processes;

- Establish a process to identify joint priorities;

- Establish mechanisms such as an alternative dispute resolution process to resolve high-level areas of jurisdiction;

- Uphold First Nations inherent right to selfgovernment; and

- Implement and explore First Nations jurisdiction through a piloted initiative.

Furthermore, the federal government announced their interest in resolving disputes between the Province and the First Nations over the lands associated with the 20year Ipperwash conflict, seeking to return the lands to the Chippewas of Kettle and Stony Point First Nation along with $\$ 95$ million in reparations (Simpson, 2015).

Yet, in spite of these developments Ontario's current approach is limited and limiting. Taking into account the manifest and latent content of the 2014 PPS and the Planning Act (1990), it is clear that provincial officials are still wrestling with how to recognize and engage with First Nations in planning policy, rather than focusing on actively addressing larger structural issues of clarity in higher-tier legislation and exploring how to integrate forms of active reconciliation in provincial planning policy. The Planning Act (1990), the PPS's overarching legislation, whether intentional or not, continues to advance the notion that First Nations are just another stakeholder and fails to provide a clear mandate on First Nations, Aboriginal and treaty rights and traditional territories (Participant Three, personal communication, June 13, 2014). Read in conjunction with section 3(9)7 of the Ontario Regulation
200/96, which outlines the requirement to give notice of a hearing for a minor variance to the Chief of every First Nation council, if the community's reserve is within one kilometre of the subject land, one could argue that the Planning Act (1990) also advances the assumption that First Nations' lands, interests and rights end at the boundaries of a reserve. Sustained and equitable relations may be a distant and ambitious aim when most local governments, based on the planning mandate provided by the Province, may assume that First Nations' interests exist within the confines of reserve boundaries. For instance, local governments may not be fully aware of the overlap between traditional territories and local government areas. Adding to this, there is still a need to integrate more explicit forms of active reconciliation in Ontario's PPS.

Recommending fundamental changes to the Planning Act (1990) and the Province's planning framework in relation to First Nations are not novel ideas in Ontario. As outlined by the Commission on Planning and Development Reform in Ontario (1993, p. 58), "the Planning Act and other legislation should provide opportunities for municipalities to work together with Aboriginal communities in addressing planning and development questions." Similar concerns over the Province's planning framework were then echoed in the 2007 Report of the Ipperwash Inquiry, as Justice Linden identified that certain conflicts resulting from conventional land use planning and policy could be avoided if "First Nations are actively and meaningfully involved in the planning or development process" (Ipperwash Inquiry, 2007 , p. 136). Changes since both of these reports and their recommendations have gradually occurred to a certain extent. For example, the recent changes to the PPS, the reparations to First Nations resulting from the Ipperwash Inquiry, and the Ontario Premier's agreement with the Chiefs of Ontario should all be applauded. Despite these developments, the Province's existing top-down policy-led approach still largely mirrors that of the early 1990s and remains firmly defined by non-Indigenous individuals, interests, and institutions. Relative to the Aotearoa New Zealand planning context, there are further changes required to Ontario's policies, perspectives and approaches.

\subsection{What Can Be Learned from the ACRPS and the Aotearoa New Zealand Planning Context?}

While the ACRPS represents only one regional policy statement under the RMA and it has inherent limitations regarding implementation similar to other New Zealand regional policy statements (Ericksen et al., 2004), relative to the PPS it is considerably more progressive with respect to recognizing and supporting Indigenous peoples in the planning process. Through addressing clarity, recognition, willingness and to a certain degree active reconciliation, the ACRPS points to several important lessons. A major reason for its relative strength as a policy statements stems from clarity and the impres- 
sive mandate on Māori people and rights provided by its higher-tier, the RMA through sections 6(e), 7(a) and 8 (Awatere et al., 2013). In Aotearoa New Zealand, this recognition of Māori in planning legislation can be traced back to major revisions in 1977 to the Town and Country Planning Act (TCPA) with recognition of the relationship between Māori people and culture and their ancestral lands and resources as matter of national significance (Awatere et al., 2013). This shift can be attributed in part to the creation of the Waitangi Tribunal in 1975, a formal mechanism to address historical grievances of Māori people (Awatere et al., 2013). Prior to the 1977, there was no mention of Māori people in the first TCPA of 1926 and slight recognition in the TCPA of 1953, but in "a very detrimental manner [as] it prevented building on land that remained in Māori title" (Kennedy, 2008, p. 7). This slight recognition in 1953 led to the alienation of land and major migrations of Māori into cities, impacting Māori culture negatively (Kennedy, 2008). Thus, relative to Ontario, the Aotearoa New Zealand planning context in general has had a longer evolving and advanced history with respect to the integration of Māori rights and knowledge (Awatere et al., 2013).

Another major lesson from the ACRPS relates to the multiple forms recognition of Indigenous peoples in the policy statement. Not only is there recognition of Māori people through the interchangeable use of English and Māori terms, but there is recognition of rights, the Treaty and ancestral lands. The use of Māori terms, although often a source of contention as complex terms can be simplified or misappropriated through English translation (Awatere et al., 2013), is highly noteworthy because it is a clear instance in policy of Indigenous peoples drawing on their own traditions, cultures and words to define their communities and central government supporting these differing forms of recognition. Likewise recognition of principles of the Treaty in the policy statement that comprise of "partnership; reciprocity; mutual benefit; active protection; and redress" is critical because it forces local authorities to build an awareness of their implications at the local-scale and to act honourably and in good faith with Māori communities and authorities (Kennedy, 2008, p. 8). Direct recognition assists in the development of a greater awareness amongst the public at large of diverging histories and the importance of these differences to fostering and sustaining mutually beneficial treaty relations. While planning tends to be forward-thinking in the management of land and resources, it is vital to understand its colonial past in order to situate the practice in its cultural context (Porter, 2006).

The Auckland Council and its regional policy statement are not perfect, but they are flexible and progressive relative to the PPS. While Māori rights and knowledge have been recognized in planning legislation since the late 1970s in Aotearoa New Zealand, Ontario has only recently begun to directly integrate recognized and affirmed rights under section 35 of the Constitution Act, 1982. The Province has a great responsibility to be inno- vative in addressing the status quo embedded in its planning policy framework, restoring relationships, and building an equitable planning system that is reflective of all treaty partners.

\subsection{Opportunities for Policy Reform in Ontario}

Ontario needs to actively reconfigure its planning policy framework in partnership with First Nations to support more just and effective planning practices. Doing so, could enhance awareness of a majority of non-Indigenous planning practitioners who may remain largely unaware of the place-based Indigenous foundations of the land and continued relevance of treaty relations and obligations to the success of the Province. Further changes could also create new opportunities for nonIndigenous communities to learn from and work together with Indigenous treaty partners. The remote approach of the federal government in Aboriginal affairs in Ontario, as seen with the recent announcement of reparations resulting from the 2007 Ipperwash Inquiry coupled with the reality that Ontario is home to the largest Indigenous population in the country places, and the recent recommendations of the Truth and Reconciliation Commission of Canada (2015) offer additional significance on this need to act promptly (Ipperwash Inquiry, 2007; Participant Two, personal communication, June 12, 2014).

\subsection{Policy Recommendations for Planning in Ontario}

Based on the findings of this comparative, the following nine (9) recommendations have been proposed to further enhance the current PPS (2014) and planning in Ontario and to assist the Province in getting to common ground; these are by no means a comprehensive set of recommendations and address the elements of clarity, recognition, willingness, and active reconciliation:

\subsubsection{Clarity}

Recommendation 1: The Province should actively seek out First Nations' involvement to amend the Planning Act (1990) to address the lack of a clear and meaningful mandate on First Nations issues and rights, and promote context-specific accords between First Nations and planning authorities where municipalities and traditional territories overlap.

Recommendation 2: The Province should prioritize relationship building by providing joint operational capacity funding to sustain long-term partnerships between First Nations and adjacent municipalities to strengthen mutual understanding and learning.

\subsubsection{Recognition}

Recommendation 3: The Province in partnership with First Nations should expand recognition in the PPS to 
include policies that acknowledge traditional territories and First Nations continued vested interest in lands outside of reserve boundaries.

Recommendation 4: The Province should alter the PPS and other aspects of its larger planning policy hierarchy to recognize First Nations as foundational partners, not just another stakeholder. This can be done by actively exploring in partnership with First Nations, the opportunities to include Indigenous terms, language and knowledge into the PPS to ensure that it reflects the shared foundations of the Province.

Recommendation 5: The Province in partnership with First Nations should provide for and support the protection of cultural heritage and archaeological resources in the PPS that are known to exist, but may be too sensitive to identify and make public through conventional planning means.

\subsubsection{Willingness}

Recommendation 6: The Province in partnership with First Nations and municipalities should develop specific guidance material for the PPS relating to the need for effective communication and equitable relationship building to address issues of capacities and understanding between municipalities and First Nations. This would be in line with the content and directive provided on guidance material in the PPS.

Recommendation 7: Taking into consideration the findings of the recent Tsilhqot'in Nation v. British Columbia (2014) Supreme Court of Canada ruling, the provincial government should be prepared to recognize Aboriginal title and amend the PPS or release additional guidance material to provide clarity on how this may affect planning with respect to consent in certain areas of the province subject to land claims and unceded territories.

\subsubsection{Active Reconciliation}

Recommendation 8: The Province should actively incorporate all findings of the Ipperwash Inquiry (2007), the RCAP (1996) and ongoing land claims into the PPS in order to directly acknowledge planning's complicity and inherent limitations.

Recommendation 9: The Province in partnership with First Nations should actively educate all Ontarians on past and current injustices, the significance of treaty relations, the shared nature and history of the territory, and the inherent place-based Indigenous foundations of the land that make up the municipalities that Ontarians work, reside and derive benefit from. This would greatly assist in addressing misunderstandings and fractured relations, and enhance the overall impact and reach of new policies in the PPS relating to municipal-First Nations relations.
It is important to reiterate that the PPS has evolved-but Ontario can learn much from the context of Aotearoa New Zealand. As planning practitioners learn from the Calls to Action of the Truth and Reconciliation Commission of Canada (2015), the hope and possibility exist for policy and plans to better reflect a commitment to getting to common ground. This requires non-Indigenous practitioners to realize they are implicated in educating themselves about Indigenous histories of the land and on the land. In turn active reconciliation and planning is not an Indigenous issue, it is everyone's issue and planners need to actively find common ground with First Nations to build more equitable planning futures in Ontario and Canada.

\section{Conclusion}

The analytical framework and ideas put forth in this article are presented as learning tools for planning practitioners at the local government-scale, who may not be fully aware of the uneven nature of planning frameworks and how ways of knowing are highly-circumscribed with respect to Indigenous peoples. The Government of Ontario has made significant advances relative to previous versions of the PPS with regards to recognizing and supporting First Nations, but relative to the Auckland Region and Aotearoa New Zealand planning context these changes are modest and remain distant from creating spaces of common ground.

With jurisdictional issues and general confusions attributed to the division of Crown responsibilities between the federal and Ontario provincial government, it is easy for some to argue that getting to common ground, similar to reconciliation, is not the responsibility of local governments or local practitioners, as they are not the Crown. However, this narrow and often default legal position ignores the responsibility of all treaty people to acknowledge the inherent Indigenous foundations of the land that make up the communities in which they work, reside and derive benefit. It also overlooks the fundamental fact that getting to common ground requires cultural changes, including a willingness on the part of non-Indigenous people to break with embedded cultural assumptions, understandings, relationships and ways of doing. In turn, this can garner greater public understanding and recognition of Indigenous peoples' continued interest in the land and ensure Indigenous peoples can actively define, on their own terms, a shared planning approach through mutual understanding and mutual learning-not as simply stakeholders, but as partners.

Changing public perspectives will be critical to this process, and planning policies, including the PPS, can serve as a vital and transformative role in building dialogue and ensuring more equitable planning futures in the province. If the Tsilhqot'in Nation v. British Columbia (2014) ruling on Aboriginal title is any indication, modest changes to the status quo embodied in the PPS and other land use and resource management policies are no 
longer acceptable. The TRC Calls to Action (2015) and resolutions by planners to own reconciliation as both a personal principle and professional principle of practice will only emerge if individuals choose to 'unsettle' the knowledge and practices that they take for granted and struggle to get to common ground with time, resources, accountability and humility.

\section{Acknowledgments}

We would like to thank the editors and two anonymous reviewers for their valuable comments on this article. We are also grateful for the support of our research colleagues involved with the Planning With Indigenous Peoples (PWIP) Research Group at Queen's University in developing this article, especially Carolyn King, Dan McCarthy, and Erin Alexiuk. This research was supported by the Social Sciences and Humanities Research Council of Canada.

\section{Conflict of Interests}

The authors declare no conflict of interests.

\section{References}

Awatere, S., Harmsworth, G., Rolleston, S., \& Pauling, C. (2013). Kaitiakitanga o ngā ngahere pōhatuKaitiakitanga of urban settlements. In R. Walker, T. Jojola, \& D. Natcher (Eds.), Reclaiming Indigenous Planning (pp. 236-259). Montreal \& Kingston: McGillQueen's University Press.

Auckland Council. (1999). Auckland Council regional policy statement. Auckland, NZ: Auckland Council. Retrieved from: http://www.aucklandcity.govt.nz/coun cil/documents/regionalplans/aucklandcouncilregion alpolicystatement/ACRPS\%20Policy.pdf

Auckland Council. (2013). The proposed Auckland Unitary Plan. Auckland, NZ: Auckland Council. Retrieved from: http://www.aucklandcouncil.govt.nz/EN/plan spoliciesprojects/plansstrategies/unitaryplan/Pages/ usingtheeplan.aspx

Barry, J. \& Porter, L. (2011). Indigenous recognition in state-based planning systems: Understanding textual mediation in the contact zone. Planning Theory, 11(2), 170-187.

Berke, P. R, Ericksen, N. J., Crawford, J., \& Dixon, J. (2002). Planning and Indigenous People: Human rights and environmental protection in New Zealand. Journal of Planning Education and Research, 22, 115-134.

Borrows, J. (1997). Wampum at Niagara: The royal proclamation, Canadian legal history and self-government. In M. Asch (Ed.), Aboriginal and treaty rights in Canada: Essays on law, equality and respect for difference (pp. 155-172). Vancouver: UBC Press.

Commission on Planning and Development Reform in Ontario. (1993). New planning for Ontario: Final report. Toronto: Publications Ontario.
Cope, M. (2010). Coding qualitative data. In I. Hay (Ed.), Qualitative Research Methods in Human Geography (pp. 281-294). Oxford: Oxford University Press.

Corntassel, J. \& Holder, C. (2008). Who's sorry now? Government apologies, Truth Commissions, and Indigenous self-determination in Australia, Canada, Guatemala, and Peru. Human Rights Review, 9(4), 465-489.

DeVries, L. (2012). Conflict on Caledonia: Aboriginal land rights and rule of law. Vancouver: UBC Press.

Dorries, H. (2014). Aboriginal rights brought to the provincial table: Ontario's new Provincial Policy Statement. Plan Canada, 54(2), 42-45.

Dorries, H. J. (2012). Rejecting the 'false choice': Foregrounding Indigenous sovereignty in planning theory and practice (Doctoral Dissertation). Department of Geography, University of Toronto, Canada. Retrieved from https://tspace.library.utoronto.ca/bitstream/ 1807/65468/1/Dorries_Heather_J_201206_PhD_the sis.pdf

Ericksen, N. J., Berke, P. R., Crawford, J. L., \& Dixon, J. E. (2004). Plan-making for sustainability: The New Zealand experience. Burlington, VT: Ashgate.

Fairweather, J. G. (2006). A common hunger: Land rights in Canada and South Africa. Calgary, AB: Calgary University Press.

Fraser, C. M., \& Viswanathan, L. (2013). The Crown duty to consult and Ontario Municipal-First Nation relations: Lessons Learned from the Red Hill Valley Parkway Project. Canadian Journal of Urban Research, 22(1), 1-19.

Gordon, D., \& Janzen, M. (2013). Suburban nation? Estimating the size of Canada's suburban population. Journal of Architectural and Planning Research, 30(3), 197-220.

Government of Ontario. (1990). Planning act (R.S.O. 1990, c. P.13). Toronto: Queen's Printer for Ontario.

Government of Ontario. (2009). Green energy act (S.O. 2009, c. 12. Schedule A). Toronto: Queen's Printer for Ontario.

Healey, P. (2006). Relational complexity and the imaginative power of strategic spatial planning. European Planning Studies, 14(4), 525-546.

Healey, P. (1997). Collaborative planning: Shaping places in fragment societies. Vancouver: UBC Press.

Hibbard, M., Lane, M. B., \& Rasmussen, K. (2008). The split personality of planning: Indigenous Peoples and planning for land and resource management. Journal of Planning Literature, 23(2), 136-151.

Ipperwash Inquiry. (2007). Report of the Ipperwash Inquiry (Vol. 2: Policy analysis). Retrieved from http:// www.attorneygeneral.jus.gov.on.ca/inquiries/ipper wash/report/vol_2/pdf/E_Vol_2_Full.pdf

Kennedy, N. (2008). Viewing the World through a wider lens: Māori and Council planning documents. Planning under a cooperative mandate (PUCM) (Māori Report 6). Hamilton, NZ: International Global Change Institute (IGCI)-University of Waikato. 
Lane, M. B., \& Hibbard, M. (2005). Doing it for themselves: Transformative planning by Indigenous Peoples. Journal of Planning Education and Research, 25(2), 173-184.

Maaka, R., \& Fleras, A. (2005). The politics of Indigeneity: Challenging the State in Canada and Aotearoa New Zealand. Dunedin, NZ: University of Otago Press.

McLeod, F., Viswanathan, L., King, C., Macbeth, J., \& Whitelaw, G. S. (2014). 2014 Provincial Policy Statement (PPS) at a glance: Changing tides in Ontario Provincial Planning Policy with respect to First $\mathrm{Na}$ tions interests. Publisher: Authors.

McLeod, F., Viswanathan, L., Whitelaw, G. S., Macbeth, J., King, C., Alexiuk, E., \& McCarthy, D. (2015). Finding common ground: A critical review of land use and resource management policies in Ontario, Canada and their intersection with First Nations. The International Indigenous Policy Journal, 6(1). Retrieved from http://ir.lib.uwo.ca/iipj/vol6/iss1/3

Memon, A., Davies, T. G., \& Fookes, T. (2007). Institutional arrangements for metropolitan government and strategic planning in New Zealand. New Zealand Geographer, 63, 43-54.

Ministry for the Environment. (1991). Resource Management Act (No.69). Wellington, New Zealand: Parliamentary Counsel Office. Retrieved from http:// www.legislation.govt.nz/act/public/1991/0069/late st/whole.html

Ministry of Municipal Affairs and Housing. (2009). Municipal-Aboriginal relationships: Case studies. Toronto: Queen's Printer for Ontario.

Ministry of Municipal Affairs and Housing. (2014a). 2014 Provincial Policy Statement. Retrieved from http:// www.mah.gov.on.ca/AssetFactory.aspx?did=10463

Ministry of Municipal Affairs and Housing. (2014b). An introduction to the Provincial Policy Statement, 2014: Rural Ontario (Draft for Discussion-February 2014). Retrieved from http://www.mah.gov.on.ca/ AssetFactory.aspx?did=10474

Noble, B. F. (2009). Promising and dismay: The state of strategic environmental assessment systems and practices in Canada. Environmental Impact Assessment Review, 29, 66-75.

Political accord between First Nations and the Government of Ontario. (2015). Retrieved from http://www.
chiefs-of-ontario.org/sites/default/files/files/Political \%20Accord-FINAL-AUGUST2015.pdf

Porter, L. (2006). Planning in (post)colonial settings: Challenges for theory and practice. Planning Theory \& Practice, 7(4), 383-396.

Porter, L. (2010). Unlearning the colonial cultures of planning. Burlington: Ashgate.

Porter, L., \& Barry, J. (2013). Planning with Indigenous customary land rights-An Investigation of shifts in planning law and governance in British Columbia, Canada and Victoria, Australia. Monash University, University of Glasgow, ESRC.

Regan, P. (2010). Unsettling the settler within: Indian residential schools, truth telling, and reconciliation in Canada. Vancouver: University of British Columbia Press.

Royal Commission on Aboriginal Peoples. (1996). Report of the Royal Commission on Aboriginal Peoples. Vol. 1: Looking Forward, looking back. Ottawa: Ministry of Supply and Services Canada.

Sancton, A. (2011). Canadian local government: An urban perspective. Don Mills: Oxford University Press.

Sandercock, L. (2004). Commentary: Indigenous planning and the burden of colonialism. Planning Theory \& Practice, 5(1), 118-124.

Simpson, B. (2015, August 15). Ratification vote to start over historic deal next week. Sarnia Observer. Retrieved from http://www.theobserver.ca/2015/08 $/ 14 /$ ratification-vote-set-to-start-over-historic-dealnext-week

Treaty of Waitangi. (1840). Retrieved from http://www. treatyofwaitangi.maori.nz/

Truth and Reconciliation Commission of Canada. (2015). Honouring the truth, reconciling for the future: Summary of the final report of the Truth and Reconciliation Commission of Canada. Ottawa: TRC.

Tsilhqot'in Nation v. British Columbia 2014 SCC 44 (Can.).

Turner, D. (2006). This is not a peace pipe: Towards a critical Indigenous philosophy. Toronto: University of Toronto Press.

United Nations. (2007). Declaration of the Rights of Indigenous Peoples. Retrieved from http://www.un. org/esa/socdev/unpfii/documents/DRIPS_en.pdf

Yin, R. K. (2009). Case study research: Design and methods (4th ed.). Thousand Oaks, CA: Sage.

\section{About the Authors}

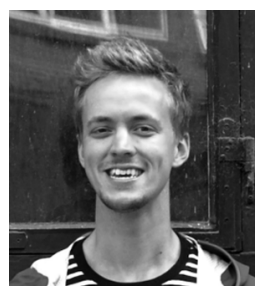

Fraser McLeod graduated with a Master of Urban and Regional Planning degree in 2014 from Queen's University at Kingston, Ontario, Canada where he was also a researcher with the Planning With Indigenous Peoples (PWIP) Research Group. His research interests have focused on critically examining provincial land use and resource management policies, plans and legislation in Ontario, and their relative capacity at recognizing and supporting First Nations. Fraser is currently based out of Calgary, Alberta as a Planner with Stantec. 

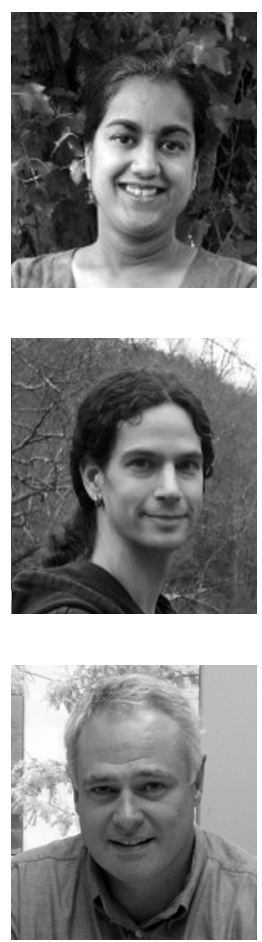

Leela Viswanathan is Associate Professor in the Department of Geography and Planning at Queen's University. As Principal Investigator with the Planning With Indigenous Peoples (PWIP) Research Group (www.queensu.ca/pwip), Leela examines how relationships have developed between Indigenous and non-Indigenous peoples in the context of colonialism and municipal land use planning and in relation to discourses about recognition and reconciliation. She collaborates with community-based and academic researchers to address both technical and adaptive planning problems at local and regional geographic scales.

Jared Macbeth is Project Review Coordinator with the Walpole Island First Nation (WIFN) External Projects Program which deals with consultation and accommodation requests within WIFN's territory. As part of the Planning With Indigenous Peoples (PWIP) Research Group, Jared investigates how language in land use policy can be altered to promote better working relationships between First Nations and local governments. He is also investigating how historical land uses and ecologies can inform modern land use decisions and bring awareness of Indigenous land use to the general public.

Graham Whitelaw is Associate Professor with a joint-appointment at the School of Urban and Regional Planning (Department of Geography and Planning) and Environmental Studies at Queen's University. As a Researcher with the Planning With Indigenous Peoples (PWIP) Research Group, Graham's research interests are focused on environmental assessment, land use planning, and community-based and multi-party monitoring and Indigenous planning. 